\title{
地殼開発とその課題
}

\author{
佐 藤 光 之助*

\section{Non-Renewable Resources from the Earth Crust and Related Problems.}

\author{
Konosuke SATO
}

本日は東京地学協会創立100周年に際し「地殼と人間生活」といら公開講演会が行なわれることになり,

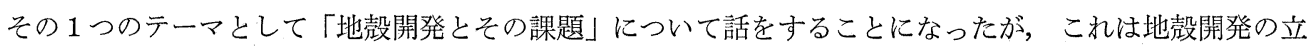
場から人間生活に欠くことの出来ない資源エネルギー問題をとりあげ，1）資源エネルギーと人間生活， 2）わが国の資源エネルギー確保の経過，３）これからの資源エネルギーと地殼開発，4）地殼開発の課 題, について述べたいと思う。

\section{I 資源エネルギーと人間生活}

人類はそれぞれの時代において自然環境のなかで自然をうまく利用して生活してきたが，しかし人間の 英知と生活レベル向上への志向は唯自然に従応した生活のみでは満足せず, 次第に地殼の中に存在する資 源エネルギーを求めるとともに，これらと調和した技術の開発によって生活レベルの向上を計るようにな った。

石器，金，銀，鉄，銅，宝石などについては先史時代から利用されてきた地下資源である。わが国でも 文武天皇の 7 世紀時代に鉱業政策が打出され，私営の鉱山が認められ 1 つの重要な産業として発足してお り，これによって国産の銅を用いて銅銭を鋳造したのが和銅開珎である。また奈良の大仏は聖武天皇の仏 法の信仰と結びついて生まれたもので，熟銅（にぎあが叔）約 520 トンを用いたもので当時の鉱山業の隆 盛と金属鉱業技術の高い水準を示すものといえよう。当時は大陸との交流も盛んで遺唐使の旅費は砂金を 携行して支弁していたと云われている。

江戸時代は鉱業の発達した時代で，主な鉱山は幕府あるいは藩の直営として開発されていた。当時は鎖 国時代であったが，海外との貿易は幕府によって管理されており，これらの決済には銅などの金属が主と して用いられていた。

また家庭用具，刀剣武具などの鉄需要は古くから盛んであったが，鉄産業は次第に発達し，砂鉄，薪炭 を使う「たたら製鉄」は中国地方山塊部に集中し，従業員10万余を超える産鉄地帯に発達していった。

欧州では数百年前に製鉄用高炉が誕生している。当初の高炉の還元剤および燃料には木炭が使用されて いた。産業革命が近づくにつれ鉄鋼の需要は増大しそれにつれ木炭の需要も著しく増加していき，当時の イギリスは国内の山々ははげ山となるといら深刻な事態に立ちいたった。この鉄工業の窮状を救ら方法と して石炭資源をもつイギリスは石炭を木炭に代わって使ら方法を研究し，石炭と鉄とを結合させる方法を 発見し (1713)，一躍鉄鋼生産国としての先導的な歩みを始めたのである。

産業革命時代，石炭の登場は蒸気機関の発展をもたらした（1781）。従来水車の出す動力にたよってい たが，蒸気機関によって必要な場所で天候などの制約を受けることなく巨大な動力をつくり出すことが出 来るようになった。蒸気機関による工業の発達は石炭などの資源地帯に漸次移動していった。ヨーロッパ

\footnotetext{
* 金属鉱業事業団
} 
のルール工業地帯，アメリカの五大湖周辺，日本の北九州などがよい例である。

「燃える石」にすぎなかった石炭は製鉄への利用，蒸気機関の発明それに続く産業革命の発展によって， その役割りは飛躍的に増大し以後 150 年間はエネルギーの主役としての地位を確保していたのである。

19世紀後半から 20 世紀にかけての石油資源の発見と内燃機関などの発達は石油といら新しい巨大なエネ ルギー資源の誕生のきっかけとなり，さらに石油化学工業の発展によって，石炭を急激に斜陽化させ石油 文化とも云らべき経済成長をもたらした。とりわ汀先進諸国は大量生産, 大量消費の工業化社会を構成し ていった。

一方金属についてはかつては人間生活の身近な範囲にその使用が限られていたが，工業化社会の発展と ともに，より多量の，またより多様な性質の材料として要求されるようになり，我々の社会を維持してい く上に不可欠の資源となってきた。現在では金属のみならず，非金属の果す役割りも極めて重要なものと なっている。

このように資源エネルギーの開発利用は人間の英知と発展への志向に基いて行なわれ，新しい社会文化 の創造への基䃈を作ってきた。しかし資源エネルギーはそれらを含む土地の問題が国際間の争いの原因に なってきたこと，またかっては植民地的搾取の対象となったことは歷史の示すところである。現在では石 油のようにその偏在性と有限性とから戦略物資化された様相を示すようにもなってきた。

一方，資源エネルギーの開発，輸送，精製，利用は自然環境に影響を与えることが重要な問題となって きた。かってはこれらに対する認識の度合が低かったこと，またこれらに対する対応策が不十分であった ことのため公害問題をひきおこした例は多く，環境保全のための対策が強く要請されている状況である。

\section{II わが国の資源エネルギー確保の経過}

わが国が近代化社会への発展の過程で資源エネルギー確保はどのように進められて来たかをふり返って みたいと思う。

幕末期に衰退の極に瀕していた金属鉱山は明治政府によって国有化され，海外技術の導入による採鉱， 製錬部門が近代化され，次第に復興していった。これらの鈗山も他の産業と同様次第に民間に払い下げら れ民間企業としての釷業が確立されその生産が急速に進展し，財閥形成の基礎を築くのに大きな役割りを 果した。特に銅については明治前半から国内の需要を満すのみならず，ちょうど世界的に電化の時代に入 っていたこともあって，電線の材料としてわが国の輸出商品となっていった。亜鉛は銀，銅，鉛などの製 鍊を妨げるものとして害物視されており，わが国には亜鉛製鍊技術はなかったが，真鍮や亜鉛鉄板などの 需要の増加によって1913年頃から亜鉛製錬が始められた。

日本には以前から砂鉄を原斜とするたたら製鉄が行なわれていたが，明治政府になって洋式製鉄技術の 育成に努めるとともに，たたら製鉄の改良にも力を入れた。磁鉄鉱を原料とする高炉操業は幕末にすでに 成功していたが，明治になって釜石鉱山の鈗石を使用する官営釜石製鉄所を発足させている。官営八幡製 鉄所設立に際しては新潟県赤谷鉱山等の鉄鈗石，二瀬炭鉱の石炭の使用を予定していたが，実際操業の段 階には中国大陸から大治鉄山の鉄鈗石を輸入するようになった。

日露戦争以後南満州鉄道株式会社が設立され，大陸の資源確保のため満州各地の地質調查が始められて いる。1909年当時の地質調査所長木戸忠太郎等によって鞍山付近において膨大な鉄鈗床が発見された。

日本における石炭の利用はます製塩用燃料として始まり，幕末の外国貿易開始後は石炭の輸出および外 国船舶への石炭補給が行なわれた。一方近代社会の発展とともに石炭の需要は増大し, まず九州筑豊地域 への中央資本の進出が始まり，石鉱業は産業としての形態を整えていった。さらに各地の炭田開発が行な われ, 明治 29 年に 1,000 万トン, 大正 2 年に 2,000 万トン, 昭和 15 年には 5,600 万トンの最高出炭量が記録 されている。この間中国大陸においても各地で炭田開発が行なわれた。

日本の石油業は新潟から生まれている。明治に大り北海道開拓使の招きで来日したライマンは政府の依 
頼により明治 9 年本邦石油の調查を行っているが，信越 2 県の総油量は米国ペンシルバニア州における 2 個の油井から出る油量にすぎないと述べている。その後多くの調查が実施されたが，その規模は小さく海 外の石油に依存せざるを得なかったのである。

石油資源に乏しいわが国では唯一の海外油田として北樺太の油田の利権を確保したが，今日主要な石油 産出国となっているところの開発はすでに米，英，蘭，仏の石油企業が多国籍化しつつ着手していたので ある。すなわち，石油開発は約120年前にアメリカで始り，19世紀後半から 20 世紀初めにかけて世界各地 に拡り，1930年代には巨大油田のあるアラビア半島へと発展していった。1930年代にはこれらの大企業は 国際石油カルテルを結成し，世界中の石油価格をアメリカの石油価格に準じて調整したので，中東の石油 生産からは莫大な利潤があがることになったのである。

このような国際情勢のなかでわが国が自主的に開発出来るような地域は余り残されてなく，また探鉱開 発技術についても先進国の新しい情報は入り難かったものと思われる。19世紀末にロイヤル・ダッチ・シ エルが開発に成功したスマトラ油田を含む南方油田はわが国にとって羡望の地と考えられるようになり， 南進論の基をなしたように思われる。

石油資源の確保に苦労していたわが国では一方において人造石油をつくる計画が進められていた。当時 わが国の液体燃料総需要を 400 万キロリットルと推定し，その半分の 200 万キロリットルを人造石油に依存 する計画がたてられ，昭和12 18年の 7 力年計画で達成する方策が進められた。これらは撫順頁岩油，石

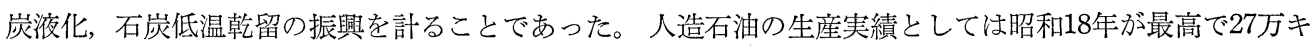
ロリットルに達した程度で，計画には遠く及ばなかったのである。

中国大陸に進出したわが国は豊富な天然資源，特に地下資源に期待をかけていた。石油の探鈗も小規模 に行なわれ，また人造石油のための頁岩，石炭の採堀試験も行なわれたが，石油問題の解決を得ることが 出来ず，終に南方油田確保という無謀ともいえる方向に進んでしまったのである。

戦後の日本はまず国内資源に依存せざるを得なかった。昭和 21 年末石炭，鉄を超重点増産の対象とする 方針がうちたてられた。終戦時には石炭は年産 2,200 万トン程度に落ちこんでしまったが，以後傾斜生産 によって徐々に回復していき昭和 36 年には戦前の水準の 5,600 万トンに達している。しかし昭和 30 年代に 入るとエネルギー革命の進展によって石炭は石油にその地位を追われ出炭量は徐々に減少し現在は年間出 炭量は2,000万トンを割るようになってしまった。

石油についても戦後国内石油資源の開発促進のための施策が行なわれたが，国内油田の産出量は極めて 少く, 経済の成長に伴って国産原油の比率は年々低下する一方であった。このような状況の時に昭和 33 年 （1958）山下太郎がサウジアラビアとクエートの中立地帯の沖合の石油利権を入手しカフジ油田を発見した ことはわが国の石油開発史上特記されることと思われる。昭和 35 年 (1960) にはインドネシア北スマトラ 油田の復旧再開のために経済協力をすることになり，そこから原油を受けとることになった。このように 昭和 30 年代前半に 2 つの海外石油開発事業が始められた。

このアラビア石油の成功は国際的に大きな反響をよび，当時ソ連，欧米に旅行中の私は各地で日本の石 油開発事業の評価を聞かされたものである。しかしその反面国内的には石油開発に対する容易な考え方を 生んだことは否定出来ないように思われる。

昭和42年 (1967) 石油開発公団が設置され海外石油探鉱開発促進に関する施策が行なわれるまでには相 当時間が掛ったといえよう。

このような経過をたどっている間に各国は油田開発に大いに力を注いでいた。同じ敗戦国であるイタリ アでも1953年にすでに ENI（炭化水素公社）が設立され，新しい探鉱装置等を充実させ 国内，海外の石 油，天然ガスの探鉱開発に集中的に力を注いでいた。

一方わが国から石油資源に期待がもてないと見離されていた中国は終戦後しばらくして新しい中国とし 
て発足し，鋭意石油探鉱を行いその建国10年までには東北の黒竜江省の大慶油田を始め幾多の油田開発に 成功し石油産出国としての第 1 歩をふみ出している。勿論新中国成立後ソ連，ルーマニア等の産油国から の技術導入があったが， 大規模な探釷活動によって幾多の油田を発見し，陸成堆積層にも大きな油田が期 待出来ることを実証したのである。ソ連においては1955と1960年の間に石油で2.3倍，天然ガスで6.5倍の 生産量の拡大を行っているが，昭和37年には当協会が共催して「ソ連に㧍ける石油鉱業の発展について」 の講演会も開催されている。

戦後の石油事情は著しい変化を示している。中東地域の数多くの大油田の発見，従来は陸上が主体であ ったものが，次第に沖合大陸棚に開発の手が拡がってきた。これらにより石油供給過剩時代をつくり出し ていったのである。1960年代のわが国の高度成長時代は石炭から石油への変換が行なわれ，非常に安い便 利なエネルギーを利用して経済成長が進められたと云えよう。

1960年代にはわが国は中東から1バーレル当り1ドル70セント程度の安い石油を輸入していた。これは 戦前に比べると $1 / 8$ の価格と云われている*。アメリカは1950年当時全世界の産油量の半分以上の 2.7 億卜 ンを生産していたが，次第にそのシェアは減り中東に追越されていき，石油輸入国に転落していったので ある。アメリカは国内石油の価格は 5 ドルであったので関税障壁をめぐらし 5 ドルの石油を使っていたわ けである。西ドイツやイギリスは外国からだけの資源に依存することの不安，また国内の石炭産業の規模 が大きいために急激に石油に転換することが出来ずエネルギー源として石炭を相当使っていた。西ドイッ で掘られた石炭から電気をおこすと，バーレル当り 7 ドルの石油を使らのと同じくらい費用がかかったと 云われている。

このように安いエネルギーに依存して高度経済成長を果して来たわが国は 1970 年代に入って深刻なエネ ルギー問題に直面するようになり，従来のエネルギーの優位性が一転して最も梁刻な立場に立たされるよ らになったのである。

このような情勢のなかで，わが国においては脱石油の声がにわかに高くなり，石炭，原子力，水力，地 熱等によるエネルギー確保およびサンシャイン計画による代替エネルギーの技術開発の施策が進められる ようになった。

戦後金属釷物資源調查として製鉄原料の自給度を高めることを目ざし，砂鉄，磁硫鉱鉄等の未利用鉄資 源の開発調查が行なわれたが，鉄鉱資源は世界的に豊富に存在することから，鉄鋼業の拡大に伴いほとん ど海外資源に依存するようになった。

ウラン資源の調査は1954年から地質調查所の手によって始められ，人形峠において唩岩型砂岩型鉣床が 始めて発見され，引続いて東濃鉱床等が見っかった。現在は動燃事業団，金属釷業事業団，民間企業によ つて国内，海外の探鉱が行なわれている。

非鉄金属釷物資源については金属鉱業事業団によって広域調查, 精密調查, 企業探鉱という三段階方式 がとられており，また海外についても探鈗開発が進められているとともに国際技術協力の立場からの調查 も継続的に行なわれている。

わが国は古くから釷山開発が行なわれ，大正初期には米国に次いで世界第 2 位の産銅国であったが，戦 後の急激な産業の発展時代に入ると金属も国内鉱だけでは需要に応じきれず，鉱石の大部分を海外より輸 入して精錬を行うようになってきた。最近国内鉱山は鉱量の枯渇，品位の低下等から国際競争力に勝てず 休山するものが増加しているが，一方では地下に潜在する鉱床の発見によって新しい鉱山の誕生，あるい は，古い鉱山での新しい鉱床の発見による再生も行なわれている。

非金属鉣物資源の開発は数多く行なわれているが，石灰石鈗業はセメント工業などの原材料として重要 なものであり，大きな産業として発展して来た。昭和 53 年には 1 億 7,000 万トンの鉱石を国内で自給して いる状態である。

*堺屋太一：わが国エネルギー問題の現状と課題，による。 


\section{III これからの資源エネルギーと地殼開発}

最近，中東諸国を中心とする石油産出国が石油の供給量および価格の面で世界の石油市場に大きな影響 を及ぼすようになり，エネルギー危機の到来が真剣に受けとめられるようになってきた。このようなエネ ルギー事情に対処する方策が必要とされているが，地球上に存在するエネルギー資源を未利用のものも含 めてより有効に利用する方策を打出していくことが緊要な問題となってきた。

一方このような工業化社会を支える原材料資源についても，低廉かつ安定した供給体制を保つことが重 要な課題である。

ところで，わが国は国産資源に乏しくエネルギー供給構造がきわめて脆弱な体質であるので梁刻な問題 となっているわけである。このためには石油依存度の低減, 非石油エネルギーの多様化, 特に新しいエネ ルギー資源の開発の方策が打出されており，また国際的にもエネルギー大量消費国であるわが国がこれら の努力をすることが要望されているところである。

地球上に存在するエネルギー資源については地殼中から開発生産される非再生資源と地球上の自然エネ ルギーのような再生可能資源とがある。前者は主として化石資源であって石油, 天然ガス, タールサンド, 油母頁岩, 石炭, ウラン等があげられる。後者は太陽, 風力, 海洋 (波力, 海洋温度差等), 植物 (バイ オケミー）等のこれから開発されていく新しいエネルギー源である。地熱は現在生きている資源であり， 両者の中間的性格のもので，適切な管理のもとでは半永久的に使用することが可能と思われるものであ る。

地殼から生産される非再生資源はエネルギーの濃集したものを採取して利用するので経済的にすぐれた ものであるが，地球上の資源賦存について地域性があるためこの不均衡を是正するため国際協調のもとで 適切な配分を行ってきたものである。しかし最近では資源の有限性が云われるようになり，急激に戦略物 資化してきたが，これに対しては地球上の資源の埋蔵量，発見量からみた適切な生産を維持することによ る安定供給の路を確保することが基本となるように思われる。

自然エネルギーを利用する方法は時間的に変化の多い非常に薄いエネルギーを如何に濃縮貯蓄するかな どの技術の確立にかかっている。地域に密着しての利用が主となり，規模の大きい経済的な供給が可能か どらかは今後の技術開発にかかっているように思われる。またこの種のエネルギー源は地球上の地球物理 的条件さらに国土の広がり，人口密度等地理的条件によっても相当格差を生ずるものであろう。

最近, Amory B. Lovins によってエネルギー政策の基本方針としてソフトエネルギーパスが提唱され ている。これはエネルギー供給の中心を化石燃料や原子力を利用する大規模集中的なシステム（ハードエ ネルギーパス）によるのではなく，太陽熱，風力等の再生可能エネルギー（ソフトエネルギーパス）によ っていわば小規模分散型のシステムによるべきという意見が出されている。またこのシステムによると今 までのように充分にエネルギーを供給することがむずかしくなるので，省エネルギーを行うことに依存す るという考え方である。これによって永続的平和への道が可能であると提言している。

これは我々の生活をエネルギー的にみて数分の 1 ないし 1 桁程度ひき下げることを意味しているように 思われる。ソフトエネルギーのみに限定したシステムはなかなか受け入れ難いように思われるが，ハー ド，ソフトエネルギーを二者択一的に扱わず，弾力的に活用していくことはこれからの課題であろう。

しかし当分の間，ソフトエネルギーはハードェネルギーの補閒的役割りを果すものと思われる。

ちなみに, 現在, 過去の日本人の 1 日当りのエネルギー消費量は, たきぎ時代は $1,000 \sim 2,000 \mathrm{cal}$. 昭 和初めの石炭最盛期は約 $13,000 \mathrm{cal}$. 現在は $100,000 \mathrm{cal}$. 弱である。

我々は金属，非金属，石材その他の資源を古くから地殼から求めて来たし，今後もそのような道をたど るものと思われる。さらに従来利用されていなかった未利用資源が将来開発利用される可能性は多分に考 えられるものである。このように我々の社会を構成する原材料などの資源は大部分地殼に依存せざるを得 
ないものといえよう。

以上述べたよらにこれからの資源エネルギーは従来にも増して地殼に依存する度合は強く, 地殼開発は これからも人類にとって極めて重要な仕事として発展していくように考えられる。

\section{IV 地殼開発の課題}

今日世界の経済大国になったわが国は資源エネルギー確保にいろいろと苦労をして来たが，前にも述べ たようにこの問題について長期的，綜合的視野にたった施策が必ずしも充分であったかどうか，この点先 進諸国に比べていささか立遅れているように思われる。特に資源エネルギーの消費について世界有数の国 であるわが国が世界汅お法資源エネルギーの探鉱開発に貢献した度合は僅かなものと云わざるを得ない 状態である。

戦後わが国は資源エネルギーを貿易上の対象として扱いそれらの有利な条件での確保に成功し，著しい 経済発展の基を築くのに寄与してきたが，今後は資源大消費工業国として国際社会のなかで長期的, 綜合 的立場にたって問題に対処する必要にせまられるものと思われる。特に地球上における資源エネルギーの 賦存とその限界, 探鉱開発動向, 資源地域の立地条件等を充分考慮して施策を進めることが基本的な課題 のように思われる。

例えば, 石油の究極埋蔵量は地質学的にみると 2 兆バーレルと云われており, 可採埋蔵量は 6,500 億バー ル程度わかっているが，毎年の生産量の増加，発見量の低下により，最近では生産量 210 億バーレル/年が 発見量150億バーレル/年を相当オーバーしてしまい石油資源の寿命に不安をもたらしていること，さらに このような効率的かっ大量供給可能なエネルギー資源としての石油に対する認識が高まったことによる産 油国の強い姿勢に影響され石油危機に直面するようになってきたわけである。従って世界的にみればまず 埋蔵量, 発見量にバランスした生産量を保つことが安定供給確保の基であり, 資源エネルギー大消費国の 日本の立場からすれば埋蔵量，発見量の増大のためさらに一層の努力が必要と思われる。

地球全般にわたる資源エネルギーの存在可能性を検討するためには，これらが化石資源であり長い地質 時代の経過をたどって蓄積された地球上の莫大な財産であるということを充分考えるべきであろう。この 点地学および関連技術の果す役割りは極めて大きいものと云えよう。すなわち 1 ）地凯の構成，2）地殼 構造発達史からみた釷床形成機構，3）地殼中の釷床形成の物理化学的過程，4）鉱床の種類，規模，分 布等 の観点から地球上の資源量の推定を試みることである。新しい地球科学の発展の著しい今日, これ らに基いた地球上の資源量の把握を常に試みていることは我々人間社会にとって重要な指針を与えるもの と思われる。

地殼中の新しい鉱体の発見は直接的に資源確保に役立つのみならず，地球上の可採埋蔵量の増大を意味 し長期安定供給の基を強化するものである。

新しい鉱体の発見にはどのような考方方で染査を行うか，またどのような技術を使うかが主要な課題で ある。探查概念は地殼，鉱床に関する上述の要素によって組みたてられるし，探査技術については地質調 查, 物理探查, 地化学探查, 試すい等が行なわれている。例えば前にも述べた中国の大慶油田等の発見は 当時考えられていた陸成堆積物には大きな油田は存在しないという概念を打ち破って勢力的な各種の探查 を実施し大油田の発見をもたらしたものと云われている。またかつて油田探査が行なわれたが終に成功し なかった地域において新しい地震探鉱技術の発展によってあらためて油田の探查に成功し開発に至った例 は数多くある。またわが国においてはグリーンタフ地域における地凯の発達, これに伴う黒鉱々床の形 成，鉱床形成に伴う諸現象の解明ならびに関連探查技術の進歩によって幾多のかくされた鉱体を発見して おり，かが国鉱業界の進展に寄与している。

このように地殼に関する学問知識および探査技術の発展によって，従来顧みられなかった地域で新しい 鉱体の発見をもたらすことが可能と思われる。従って地殼中に存在する資源量の限界は，地殼に関する科 
学技術の発展の度合に応じて挔大していくものと云えるであらう。

これからの資源エネルギーの安定的確保のためには地球上の埋蔵量の把握, 新しい鉱体の発見が不可欠 と思われますが，このためには資源評価，資源探查活動を幅広く進めるとともにそれらの根底となる地殼 に関する科学技術の発展を計ることが基本的課題のように思われる。

次に石油，石炭，地熱，金属鉱物等の資源についての問題点を述べることにする。

石油資源：エネルギー源の歴史的変遷を見ると薪一石炭一石油・天然ガスの過程をたどって来たが，石 油は効率の高いエネルギーでかつ液体であるため生産, 輸送等が非常に便利なこと, 石炭よりは燃焼によ る污染度が少いなど有利な点が多く，石炭に代って石油時代をつくり出した意義は充分らかがえるもので ある。今後の社会においてエネルギーを石油にどの程度依存出来るかを見極めることは重要なことで，こ れによって工業化社会の維持に重要な影響を与えるものと思われる。このような情勢のもとでかくされて いる石油資源の発見，埋蔵量の増大のため努力することが世界的な課題であろら。

わが国は石油資源の探釷開発に関しては前にも述べたようにおくれて出発したものであって，石油多消 費国としては探釷開発体制，研究開発，教育等の面で弱体と云わざるを得ない。探鉱開発投資はある程度 行なわれるようになったが，国際的に通用する技術力をもってオペレーターの役を果し得る企業は限られ ている。また国際的にみて探鉱開発投資にしても石油消費量に比べ机ば著しく低いものである。自由世界 の石油の $11 \%$ 程度を消費するわが国が探鉱開発投資については最近 $3 \%$ 程度行っているにすぎないし，以 前はさらに僅かなものであった。今日までの世界の石油開発へのわが国の寄与は極めて低いものと思われ る。

地球上の新しい地域への探鉱活動の拡大については辺地，深海，極寒地等の条件の悪い地域に多くが向 けられるであろう。このような墨条件のもとでの探鉱開発のための技術力の強化も重要な課題と思われる。

石炭資源：石油危機が叫ばれるようになるとこれに代る膨大な量の代替エネルギーが必要となり，石炭 が見直されるようになってきた。石炭はヨーロッパや北アメリカにおける産業革命の原動力となったもの で，1世紀以上の間工業用，家庭用の主然料であったものである。

地球上の石炭資源については多くの埋蔵量が推定されており，潜在的採掘可能な石炭は 12 兆バーレル石 油相当（1,000バーレル石油 2210 トン石炭）で石油の究極埋蔵量の 6 倍，経済的に採掘可能の石炭の量は 3 兆バーレル石油相当で石油可採埋藏量の約 5 倍に相当する。既知資源の大部分は北アメリカ, ソ連と東 ヨーロッパ，西ヨーロッパ，中国，オーストラリア等に埋蔵されている。石炭資源の埋蔵量は非常に大き な数字となっているが，資源の賦存状態，立地条件などによってそれらの経済性が大きく左右されるもの と思われる。近年主要な石炭資源保有国での石炭開発を目ざして，欧米の石油あるいは非鉄金属等の巨大 企業の進出は目覚ましいものである。例光ばオーストラリアに㧍いては1985年の生産の76\%（出資比率分 だけでは $42 \%$ )，輸出量の $68 \%$ （同上46\%）に影響を与えうるまでになっていると推定されている。同様 に米国，カナダでもかなりの影響力を持っに至っているようである。

石炭の採掘には坑内掘, 露天掘が行なわれているが, 坑内採掘は学働集約的であり債金の上昇が石炭の 価格に直接影響を与えること，坑内採掘が安全と健康のため厳しい規制がかけられることなどが問題とな るであろう。石炭の大幅の増産のためには露天掘りの拡大が必要となるが, これは地域の環境, 経済, 社 会問題に大きな影響を与えるものである。石炭生産にはこれらの不確実な因子が大きく影響を及ばすもの で，今後石油に代るエネルギーとして大量生産を行う場合如何にしてこれらを解決していくかが大きな課 題のように思われる。

石炭の輸送，利用の面でもむずかしさがある。固体である石炭の輸送は流体である石油，天然ガスに比 べて環境的, 社会的影響, 設備の充実に対して充分配慮することが必要であろう。さらに例えば石炭と石 油の混合体（COM：Coal-Oil-Mixture）のような新しい方式による技術の確立も考虑すべきものと思わ 
れる。

石炭利用の面では排煙，灰の処理の問題がある。もし適当な管理をせずに多量の石炭を燃やせば空気を 污染し環境や天候に影響をもたらす恐れも考えられる。あまり環境等に影響を与えないように石炭を然や すための公害対策技術の向上は石炭利用の拡大に通ずるものと思われる。灰の処理についてはこれを未利 用資源の立場からその活用を検討すべきであろう。

石炭の液化ガス化の技術開発は最近かが国では昭和49年 (1974) から代替エネルギー技術開発のサンシ ヤイン計画の 1 つしてとり上げられており，現在加速的にこの計画を推進する方策が進められている。

石炭液化の歴史は古く，前にも述べたように戦前から石油資源のそしい日本，ドイツにおいて燃料自給 政策の一環として行なわれた。また戦後米国は石油不足時代を予想してこの研究を行ったが，間もなく中 東大油田発見によって中止の状態であったが，1960年頃から再び石炭利用研究を開始している。現在では 先進諸国でこの種の技術開発を進めているが，自国内で石炭増産の期待がもてないわが国としては炭質と 液化技術，開発された技術の活用方式とのかね合いから海外の資源確保と液化技術開発とを今後どう結び 付けていくかは重要な課題と思われる。

地熱資源：地殼中の地熱現象は各地質時代に認められるものであるが，現在利用し得る熱エネルギーと しては地殼中の新しい地熱現象を対象と考えねばならない。

地熱資源は地球内部からの熱によるもので熱源としてはマグマ貫入による局部的な熱源とマントルの高 まりのような地域的払がりをもつ熱源とが推定されており，前者は数 $\mathrm{km} \sim 10 \mathrm{~km}$ 程度，後者は $20 \mathrm{~km}$ 以 上の深度とされている。

$10 \mathrm{~km}$ 以浅に賦存する熱量を対象とした場合, 基礎資源量として $3 \times 10^{26} \mathrm{cal}$ 以上の熱量の包蔵が期待 され，化石燃料資源から得られる熱量に劣らないものと推定されている。

地下の熱エネルギーを採取する方法としては現在のところ地熱流体を採取しこれから熱エネルギーをと る方法がとられており，一般的には地下にある天然に形成されている地熱流体が対象となるが，天然の地 熱流体の存在しない高温岩体の場合には，人工的に水を注入し地熱流体を涵養し，この地熱流体を採取す る方法が研究されている。

火成活動によって生じた浅い局部的な熱源の場合には貫入岩体および周辺岩石からなる高温熱源に循環 水が近づき対流によって加熱され地熱熱水系が形成される。これを火山性地熱資源とよんでいるが, 熱源 からの熱の供給, 地下水の挙動, 貯留層の発達状態によって熱水型, 蒸気卓越型, 高温岩体型など色々の 形態をとっている。

この種の地熱資源は新生代の火山活動および造山運動の活発な地域に賦存しておう, 環太平洋火山帯, 地中海, ヒマラヤ造山帯, 東アフリカ地溝帯および大西洋中央海領系に属する地域等において認められて いる。

新生代の造山運動に伴って生じた褶曲山脈の周辺部に発達する堆積盈地から 高温熱水が産出しエネルギ 一源として使用されている例がある。この熱源は地域的なマントルの高まりによるものと推定されてお り，非火山性地熱資源あるいは堆積型地熱資源といわれている。ハンガリー盈地，ソ連の山間盈地などは 代表的なものとして知られており，時にはこれらの熱水貯留層が異常高圧層となって熱エネルギーととも に力学的エネルギーを有するものがあり Geopressure 型地熱資源とよばれている。米国のメキシコ湾盈 地，ハンガリーのカルパチヤ盈地などに認められている。

地熱エネルギーの利用は他の資源とは異なり開発地点において他のエネルギーに変換するか, 開発地点 周辺の直接的利用に限定される。地熱発電は電気エネルギーへの変換を行うもので, 天然蒸気を使った低 温, 低圧の火力発電に相当するものである。

現在, 蒸気卓越型地熱資源としては米国のガイサーズ, イタリアのラルデレロ, 日本の松川等, 熱水型 地熱資源としてはニュージーランドのワイラケ,メキシコのセロプリエト, 日本の八丁原, 葛根田等におい 
て商業ベースの開発が行なわれている。高温岩体型地熱資源については米国のニューメキシコにおいて熱 出力 $5,000 \mathrm{KW}$ の熱抽出に成功し, 熱出力 $2 \sim 5$ 万 $\mathrm{KW}$ プラントの研究開発を始めるところである。

米国のガイサーズ地区発電所は $110 \mathrm{MW}$ のプラントを 1 単位とし開発を進め, 現在 $850 \mathrm{MW}$ に達し, さらに開発を進めていく計画をもっている。蒝気卓越型地熱資源は経済性にすぐれており, 以前から大型 石油火力発電所のコストと太刀打出来るものと云われていた。わが国の松川地熱発電所も経済的にすぐれ たものと云えよう。

熱水型地熱資源の場合には蒸気のみでなく熱水を伴うもので，この熱水は環境保全のため地下に還元し ている。従って経済性は蒸気卓越型よりは劣るが，今後は熱水発電の技術開発，その他の技術改善によっ て経済性を高めていくことが可能と思われる。現在わが国では岩手県葛根田，大分県八丁原等において 5 万 $\mathrm{KW}$ 規模の発電が行なわれているが，これらの地区においても今後さらに開発が展開されると思われ る。

世界有数の火山国であるわが国では数少い国産エネルギー資源である地熱資源の開発を促進することは 必要と思われるが，このために大規模深部地電発電のための調査研究が進められている。これは深部に存 在する地熱資源の実体の究明, これらの開発に伴う環境保全技術の確立, 探査, 掘削技術の確立等を目ざ すものである。地熱資源の実体の究明のためには, 地質構造, 後期新生代火山活動, 関連する熱源, 水文 学的環境, 熱構造（熱流量, 地熱流体の化学成分, 変質鉣物の種類とその分布等から推定）ならびに地熱 貯留層の解明が必要となり, このためには各種地質調查, 物理探査, 地化学探查等の地熱資源に対する探 查技術の確立，地熱掘削技術の確立が重要な課題となっている。

しかし一方，地熱資源の開発の歴史は浅く，また複雑な火山活動に関連する異常現象を取扱らことから 未解決の問題が数多く残されており，このような地熱現象に関する地球科学的研究の発展が期待されてい るところである。

金属鉱物資源：非常に古い歴史をもつ銅，金，鉄のような各種の金属の利用は工業化社会のなかで急速 に伸展を示し，これからもさらに拡大していくものと思われる。この種の資源に関しては，現時点では石 油資源のような資源有限説は一般の人々の関心を引くまでには至っていないが，最近になって金属の供給 の限界にっいての論説などが次第に見られるようになってきた。将来の社会にとって代替のむずかしい金 属は代替が考えられるエネルギーよりも本質的に重要な課題を抱えているようにも考えられる。

地殼中の資源量については最近いくつかの論文が出されており，わが国でも関根 (1962), 矢島 (1976), 立見* (1979)，茂木 (1979) などによって論じられている。また B. J. SKINNER は鉄，アルミニウム， チタンなど地球化学的に豊富な金属と銅, 鉛, 亜鉛, 金, 銀, 水銀など地球化学的にそしい金属について 地殼中の品位一量の分布曲線**を示している。これらは目下の処定性的な表現に止っているようである が，今後さらに多くのデータからの検討を行うべき問題と思われる。しかし SKINNER の示した分布曲線 の意義は同じ金属であっても地球化学的に豊富な金属と乏しい金属とでは利用し得る地殼中の資源量の限 界が異なることを示している。地球化学的にそしい金属については採掘品位を下げても経済的に供給可能 量は増加せず，ある限界をもつものであると論じられている。米国において行なわれた非再生金属鉱物資 研究集会 (1976) においてはこの考え方に基礎をおいて金属鉣物資源確保の討議が行なわれている。

今から 20 数年前に石油資源の限界についてあまり気に掛计なかった我々は金属鈗物資源量について今後 資源の実体の把握および地球科学的検討を進めていくことは欠かせない課題と思われる。

一方世界の金属鉱物資源の探査開発が進むにつれ先進開発国では地表に微候をもつ鉱床については大部 分が探查開発され，これからは潜頭鉱床をさがし開発しなければならない時代に入っているように思われ る。このような傾向は古い歴史をもつわが国の鉱山業においてはすでに以前から経験しているとこらであ

* 立見辰雄博士には講演後有益な資料を賜わりここに厚く御礼申上げる。

**茂木 睦: 地学からの資源論, 地学雑誌 Vol. 88, No. 4, 1979, 第14図参照。 
る。米国に㧤いても1960年以降新釷床の発見率が急激に落ちこんでしまった。これは地表に示徽を求める 露頭探查から深部の潜頭鉱床の探査へと大きく変化していったため探査技術が充分対応出来ず，従来のテ ンポで新鉱床が発見出来なかったためと云われている。

從来地表附近に賦存する低品位大規模釷床の露天掘開発による大量生産は金属の供給に大きな役割りを 果してきた。これからのこの種の鉱床の開発は釷床賦存の深部化，エネルギー多消費の制約，鈗害対策等 によって色々と制約を受ける場合が多くなる。このため新しい開発技術の確立に努力が向けられている が，さし当ってはむしろ高品位鉱床の効率的開発に多くの関心が払われているように思われる。

ところで，金属鉱床は石油，石炭，地熱等の鉱床に比べて水平的拡りは限られた範囲に濃集されている 場合が多く，また鉱化作用といら異常な現象に伴う不確定要素に大きく支配されるため石油，石炭の場合 に比べて地質構造との対応が複雑であることから，新しい潜頭釷床の発見には幾多のむずかしさが残され ている。勿論今日まである程度の潜頭鉱床の発見に成功して来たが，これからの資源の供給のためには潜 頭鉱床の開発に依存する割合が段々と多くなっていくことを考えれば，潜頭鉱床に対する効率的な探查技 術を開発していくことは極めて重要な課題のように思われる。

\section{$\mathbf{V}$ む び}

人間社会は地殼からの資源エネルギーによって著しい発展をとげ，これからも我々の社会を維持してい くためには大部分の資源エネルギーを地殼から求めざるを得ないと思われる。狭い国土のなかで工業化社 会を作って来たわが国は資源エネルギーの大部分を海外に依存してきたが，これからもその傾向は長く続 くものと思われる。

最近石油に関し地球上の資源量㧍よび発見量と工業化社会における資源消費量との間の均衡がくずれ， 国際協調による資源の配分に摩擦が生ずるようになってきた。これは現在石油を中心としておこっている が，将来他の資源エネルギーについてもこのような恐れがないとはいい切れないように思われる。

このためには資源エネルギーの利用面の改善を計るとともに, 地球上の新しい資源の発見, 資源量の増 大に努め, 資源の安定した国際的配分の環境を作っていくことは資源大消費国である工業先進国の務めの ように考えられる。

わが国は資源小国であるといってただ安易に海外の資源にたよるだけでなく，自らが資源に関する科学 技術の振興を計り，世界の資源量の把握ならびに探釷開発活動の積極的推進を計ることが重要な課題のよ らに思われるのである。

\section{参考文献}

1）片山信夫（1965）：地下資源の歴史, Energy Vol. 2, 2.

2) 通商産業省釷山石炭局 (1971) : 資源問題の展望.

3）石油資源探査技術に関する基礎資料（1974）：科学技術㕂資源調查所資料第26号.

4）金属釷物資源探查技術汇関する基礎資料 (1974)：科学技術庁資源調查所資料第27号.

5）黑岩俊郎（1979）：資源論ノート，ダイヤモンド社.

6）堺屋太一講演録（1979）：我が国エネルギー問題の現状と課題，通商産業調查会.

7）中国経済研究所編 (1975)：中国資源総覧.

8) 斉藤 隆, 神原 達 (1979)：中国の石油，石油の開発，Vol. 12，3，4，5.

9）オルージェフ, エス.エー. (1963)：ソ連に扔ける石油鉱業の発展について, 地学椎誌, Vol. 72.1

10)総理府編 (1977)：時の動き, 明日のエネルギー。

11）エイモリー, ロビンス著, 室田泰弘, 随屋治紀訳 (1979) : ソフトェネルギーパス一永続的平和へ の道一, 時事新報社.

12）産業技術審議会（1979）：サンシャイン計画の加速的推進戦略，一中間とりまとめ一.

13）矢部 孟 (1978)：わが国石油開発の新しい展開，石油技術協会誌，Vol. 43，5.

14）グリフイス，E. D. クラーク，A. W.(1979)：代替エネルギーとしての石炭，サイエンス Scien- 
tific American 3 日本版

15）資源，No. 205，石炭利用技術の研究一特集，資源協会.

16）資源エネルギー庁石炭部監修(1979)：コール・ノート，資源産業新聞社.

17）佐藤光之助 (1977)：わが国の地熱エネルギー開発をいかに発展させるか，地熱，Vol. 14， 3.

18）-(1979）：物理探釷技術の歩みと展望，物理探鉱，Vol. 32，2.

19）陶山淳治 (1978)：エネルギー資源としての地熱開発. 地熱発電に関する講演要旨, 新技術開発事 業団.

20）関根良弘(1962)：鉱石元素の濃集と地殼に打ける現出頻度との関係，鉱山地質12.

21）矢島淳吉 (1976)：世界の銅，鉛，亜鉛鈗床の規模について，一定量的な鉱床論の試み一その 1 , その 2 . 鉱山地質 26 .

22）立見辰雄 (1979)：総鉱物資源量見積りのための 1 つの試み，鉱山地質 $29(4)$.

23) 茂木 睦 (1976) : 地学からの資源論, 地学雑誌, Vol. 88, 4.

24) SkINNER, Brian J. 立見辰雄訳 (1978)：A second iron age ahead?，日本の科学と技術 19 (191).

25) Report On The Workshop "Research Frontiers in Exploration For Non-Renewable Resources " (1976): The Pennsylvania State University.

26) Report on The Workshop on Mining Geophysics-Geophysics Applied to Detection and Delineation of Non-Energy Non-Renewable Resources. (1976) : The University of Utah.

27）鉱物資源探查技術調查団報告 (1978)：米国に掞ける鉱山物理探査及びレモートセンシング技術, 金属鉱業事業団. 